\title{
TnphoA mutants of Providencia alcalifaciens with altered invasiveness of HEp-2 cells
}

\author{
MOTIUR RAHMAN, SHIRAJUM MONIRA*, SHAMSUN NAHAR, MOHAMMAD ANSARUZZAMAN, \\ KHORSHED ALAM, MUNIRUL ALAM* and M. JOHN ALBERT†
}

International Centre for Diarrhoeal Disease Research, Bangladesh (ICDDR, B), GPOBox 128, Dhaka-1000, * Department of Microbiology, University Dhaka, Dhaka, Bangladesh and †Department of Microbiology, Faculty of Medicine, Kuwait University, Kuwait

\begin{abstract}
Recent studies have shown that Providencia alcalifaciens is a diarrhoeal pathogen. It may cause diarrhoea by an invasive mechanism, as it invades cultured mammalian cells in vitro and intestinal epithelial cells of experimentally inoculated rabbits in vivo. To locate the gene(s) involved in invasion, TnphoA mutants of a diarrhoeal isolate of $P$. alcalifaciens were generated. Compared with the parent strain, these mutants exhibited negligible invasion and actin condensation in HEp-2 cells. TnphoA insertion was located in fragments of $4.9 \mathrm{~kb}$ and $11.1 \mathrm{~kb}$ of the bacterial chromosome by Southern blot. These mutants did not secrete a $28-\mathrm{kDa}$ protein, which may be involved in invasion. It should be possible now to study the gene(s) involved in invasion of $P$. alcalifaciens with these mutants. This investigation is another example of the usefulness of TnphoA mutagenesis in the study of bacterial virulence genes.
\end{abstract}

\section{Introduction}

There are five species in the genus Providencia [1]. At least one species, $P$. alcalifaciens, has been implicated in diarrhoea. The evidence for an aetiological role of $P$. alcalifaciens in diarrhoea has come from studies on travellers' diarrhoea [2], case-control studies of diarrhoea [3] and pathogenicity studies of isolates [4]. The pathogenicity studies have indicated that the organism may cause diarrhoea by an invasive mechanism [4-7]. The bacterial isolates invade cultured mammalian cells in vitro [4-7], induce fluid accumulation in the ligated rabbit ileal loop [4] and induce diarrhoea in the removable intestinal tie adult rabbit diarrhoea (RITARD) model [4]. Electron microscopy studies of interaction of the bacterium with rabbit ileal mucosa suggested that there are two modes of invasion of enterocytes: directly through the apical surface and laterally through the intercellular tight junction [5]. Invasion of epithelial cells in vitro is associated with condensation of actin filaments, and both invasion and actin condensation can be inhibited by cytochalasin D,

Received 24 July 2001; revised version received 18 Dec. 2001; accepted 4 Feb. 2002.

Corresponding author: Professor M. John Albert (e-mail: john@hsc.kuniv.edu.kw). an inhibitor of microfilament formation [6]. Even though some isolates of $P$. alcalifaciens carry plasmids, isolates with and without plasmids were found to be equally invasive, indicating that chromosomal genes, not plasmid genes, are involved in invasion [8]. Also, no homologous sequence corresponding to virulence genes of invasive bacteria such as Shigella spp., Yersinia enterocolitica and Y. pseudotuberculosis could be found [8]. In many bacteria, genes encoding surface-exposed or secreted products can be identified by $\operatorname{Tn} p h o A$ mutagenesis. The mutants are detected by screening for alkaline phosphatase activity on an indicator medium $[9,10]$. In many invasive bacteria, including Shigella spp., secreted products are involved in invasiveness [11]. It was reasoned that the gene(s) associated with invasion in $P$. alcalifaciens encodes surface-exposed or secreted products. Therefore, TnphoA mutants of $P$. alcalifaciens were generated and studied to locate the gene(s) involved in invasion.

\section{Materials and methods}

Bacterial strains and media

$P$ alcalifaciens 2939/90, a wild-type, spontaneous tetracycline-resistant strain of $P$. alcalifaciens isolated from the rectal swab of a patient with diarrhoea, was 
used as the recipient strain to generate mutants [4]. Escherichia coli SM10 $\lambda$ pir containing plasmid pRT733 was used as the donor for TnphoA. The plasmid pRT733 contains TnphoA in a suicide vector [10]. Shigella flexneri 2a $611 \mathrm{R}$ and E. coli K-12 were used as positive and negative controls in invasion assays [4]. The media used for growing bacteria were Luria broth (LB) or Luria agar (LA). Whenever incorporated in media, kanamycin was used at $30 \mathrm{mg} / \mathrm{L}$, tetracycline at $15 \mathrm{mg} / \mathrm{L}$ and gentamicin at $100 \mathrm{mg} / \mathrm{L}$.

\section{TnphoA mutagenesis}

TnphoA mutagenesis of $P$. alcalifaciens 2939/90 was performed by conjugation as described previously [10]. The donor strain of $E$. coli SM $10 \lambda$ pir was grown in LB with kanamycin and the recipient strain of $P$. alcalifaciens $2939 / 90$ was grown in LB with tetracycline on an orbital shaker (Innova 4300, New Brunswick Scientific, NJ, USA) at $120 \mathrm{rpm}$ at $37^{\circ} \mathrm{C}$ for $20 \mathrm{~h}$. The bacteria were harvested by centrifugation, washed once in phosphate-buffered saline (PBS, $\mathrm{pH}$ 7.2) and resuspended in LB to a final concentration of $10^{9} \mathrm{cfu} / \mathrm{ml}$ each. The donor and recipient strains were mixed at a ratio of $10: 1$ and incubated with vigorous shaking $(120 \mathrm{rpm})$ at $37^{\circ} \mathrm{C}$ for $4 \mathrm{~h}$. Then $200-\mu 1$ samples of the mating mixed culture were spread on LA plates containing kanamycin, tetracycline, dextrose $(0.2 \%)$ and the chromogenic substrate, 5-bromo, 4-chloro, 3-indolyl phosphate (XP; Sigma) $100 \mu \mathrm{g} / \mathrm{ml}$ and incubated at $37^{\circ} \mathrm{C}$ for $24-48 \mathrm{~h}$. Transconjugants with TnphoA inserted in a functional gene (as indicated by deep blue colonies) were selected. After checking the purity of the colonies by streaking on fresh XP plates, the colonies were stored in LB containing kanamycin and tetracycline and glycerol $15 \%$ at $-70^{\circ} \mathrm{C}$ for further study.

\section{Assay for motility}

The motility of wild-type $P$. alcalifaciens and its TnphoA mutants was determined by the hanging-drop method with a 6-h LB culture incubated at $37^{\circ} \mathrm{C}$ and also after incubation for $18 \mathrm{~h}$ at $37^{\circ} \mathrm{C}$ of an inoculated soft nutrient agar tube.

\section{HEp-2 cell invasion assay}

The HEp-2 cell invasion assay was performed as described by Albert et al. [4]. HEp-2 cell monolayers in 24-well cell culture plates (Corning, NY, USA) grown in minimum essential medium (MEM) containing fetal bovine serum (Gibco BRL, Grand Island, NY, USA) $10 \%$ were washed twice in MEM and infected with wild-type $P$. alcalifaciens and its TnphoA mutants $\left(1 \times 10^{7} \mathrm{cfu}\right.$ each to give a multiplicity of infection of 100). S. flexneri $2 \mathrm{a} 611 \mathrm{R}$ and E. coli K-12 were used as positive and negative controls respectively in each experiment. After a 2-h infection period, the monolayer was incubated for $1 \mathrm{~h}$ in MEM containing gentamicin to kill extracellular bacteria (the parent strain and mutants were susceptible to gentamicin). Various dilutions of lysed monolayer were plated on LA plates for enumeration of intracellular $S$. flexneri 2a, E. coli K-12 and wild-type $P$. alcalifaciens. For TnphoA mutants, the LA plate contained both kanamycin and tetracycline. The experiments were performed three times in duplicate.

\section{HEp-2 cell-associated organisms}

To determine cell-associated organisms, the assay was performed as described above for invasion. However, after the 2-h infection period, the monolayer was washed three times with MEM, lysed and varying dilutions were plated for enumeration of bacteria.

\section{Fluorescent actin staining (FAS) test}

The ability of bacteria to condense actin was tested in a HEp-2 cell assay as described previously [4]. The degree of condensation was scored on a scale of $0-4+$ [6]. S. flexneri $2 \mathrm{a} 611 \mathrm{R}$ and E. coli K-12 were used as positive and negative controls, respectively, in each experiment. The experiments were performed three times in duplicate. The condensation produced by $S$. flexneri was assigned a value of $4+$.

\section{Southern blot hybridisation}

The chromosomal DNA was extracted from the wildtype $P$. alcalifaciens and its mutants by the standard phenol-chloroform method [12]. It was then digested with BamHI enzyme (Gibco BRL) according to manufacturer's protocol. This enzyme does not cut within the TnphoA gene. The digested DNA (30 $\mu \mathrm{l})$ was separated on an agarose (Type II: medium EEO; Sigma) $0.8 \%$ gel and transferred to a nylon membrane (Hybond TM-N ${ }^{+}$, YA0147; Amersham, IL, USA) with a vacuum blotter (BioRad, CA, USA). The DNA material was fixed to the membrane by exposure to UV light. A portion of kanamycin resistance gene was used as a probe to locate TnphoA insertion in the chromosome. The kanamycin gene was amplified from recombinant plasmid pRT773 with primers kanI (5' AGC TGG GGC GAG CTC TGG TAA GGT 3') and kanII (5' AAA GGG AAT AAG GTC GAC ACG GAA 3'). The amplified product was labelled by digoxigenin-11-dUTP by the random primer extension method with a DIG DNA labelling and detection kit (Boehringer-Mannheim, Mannheim, Germany). The hybridisation and detection were performed according to the manufacturer's instructions.

\section{Antiserum to P. alcalifaciens}

Rabbit polyclonal antiserum to the wild-type $P$. alcalifaciens was produced by a previously described protocol [12]. Briefly, the culture was grown in LB at 
$37^{\circ} \mathrm{C}$ for $20 \mathrm{~h}$ on an orbital shaker (Innova 4300 , New Brunswick Scientific). Antiserum was produced in an adult New Zealand White rabbit. The rabbit was given four intravenous injections at weekly intervals, with a booster injection 3 weeks after the last injection. The amount of culture administered each time was $500 \mu 1$. The rabbit was exsanguinated 7 days after the last dose.

\section{SDS-PAGE and immunoblotting}

Single colonies of the parent $P$. alcalifaciens were grown in $5 \mathrm{ml}$ of LB and those of mutants in $5 \mathrm{ml}$ of LB with kanamycin and tetracycline. The cells were pelleted by centrifugation and the protein in the supernate was precipitated with ammonium sulphate $60 \% \mathrm{w} / \mathrm{v}$. The proteins from lysed whole-cell pellet and supernate were analysed separately. Samples containing $10 \mu \mathrm{g}$ total protein were separated on $10 \%$ SDS-PAGE and the separated proteins were transferred to a nitrocellulose membrane for immunoblotting [13]. The membrane was exposed to rabbit polyclonal antiserum to $P$. alcalifaciens ( 1 in 500 dilution) and then to affinity-purified horseradish peroxidaseconjugated swine anti-rabbit immunoglobulin $\mathrm{G}$ (1 in 500 dilution) (Sigma). Bound conjugate was detected with the substrate containing ice-cold methanol $16 \%$, 4-chloro, 1-napthol $0.05 \%$ and $\mathrm{H}_{2} \mathrm{O}_{2} \quad 0.025 \%$ in Trisbuffered saline.

\section{Results}

\section{Generation of TnphoA transconjugants}

Two separate experiments yielded 59 mutants from $P$. alcalifaciens 2939/9. The frequency of transfer of TnphoA varied from $5.0 \times 10^{-9}$ to $5.0 \times 10^{-8}$.

\section{Motility}

Like the wild-type strain of $P$. alcalifaciens, all the three mutants were motile by both hanging-drop method and soft agar method.

\section{HEp-2 cell association, invasion and actin condensation by bacteria}

Of the 59 mutants, 13 showed reduced invasion compared with the parent strain on initial screening. However, on further screening, only four mutants (nos 23, 47, 63 and 78) showed consistently reduced invasion. These mutants only were studied further. The cell association, invasion and actin condensation are shown in Table 1. The parent and mutant strains showed similar levels of cell association. However, compared with the parent strain, the mutants showed negligible invasion. There was a 33-111-fold reduction in invasion. Whereas the parent strain showed strong actin condensation, the mutants showed doubtful condensation.

\section{Southern blot hybridisation}

The TnphoA insertion in the four invasion-deficient mutants was located by Southern blot hybridisation. There appeared to be a single insertion in all four mutants. The transposon was located in a fragment of $4.9 \mathrm{~kb}$ in mutant nos 23 and 47, and in a fragment of $11.1 \mathrm{~kb}$ in mutant nos 63 and 78 (Fig. 1).

\section{Immunoblot analysis of proteins}

To investigate whether TnphoA insertion had disrupted the expression of any functional gene encoding secreted fusion protein, the protein profiles of the parent and the four mutants (nos 23, 47, 63 and 78) were studied by immunoblotting. This showed that all four mutants failed to secrete a $28-\mathrm{kDa}$ protein. Fig. 2 shows the presence of the $28-\mathrm{kDa}$ protein in the parent strain and mutant no. 51 (a mutant that was not invasion-deficient) and its absence in mutant nos 23, 47, and 63. No differences between the parent strain and the mutants could be detected in the immunoblot when the lysed whole-cell pellet was analysed (data not shown).

\section{Discussion}

TnphoA insertion mutagenesis has been used successfully to characterise genes encoding surface-exposed or

Table 1. Cell-association, invasion and actin condensation of $P$. alcalifaciens and its mutants with HEp-2 cells*

\begin{tabular}{|c|c|c|c|c|}
\hline \multirow[b]{2}{*}{ Strain } & \multicolumn{2}{|c|}{ Bacteria $(\mathrm{cfu}) / \mathrm{ml}$} & \multirow{2}{*}{$\begin{array}{c}\text { Intracellular } \\
\text { bacteria } \\
\text { relative to } \\
\text { inoculum }(\%)\end{array}$} & \multirow{2}{*}{$\begin{array}{c}\text { Actin } \\
\text { condensation }\end{array}$} \\
\hline & Cell-associated & Intracellular & & \\
\hline P. alcalifaciens (2939/90) & $2.0 \times 10^{5}$ & $1.0 \times 10^{4}$ & 0.1 & $3+$ \\
\hline Mutant 23 & $2.5 \times 10^{5}$ & $3.6 \times 10^{2}$ & 0.003 & \pm \\
\hline Mutant 47 & $2.9 \times 10^{5}$ & $9.0 \times 10^{1}$ & 0.0009 & \pm \\
\hline Mutant 63 & $3.0 \times 10^{5}$ & $1.8 \times 10^{2}$ & 0.001 & \pm \\
\hline Mutant 78 & $3.2 \times 10^{5}$ & $2.9 \times 10^{2}$ & 0.002 & \pm \\
\hline S. flexneri 2a (611R) & ND & $4.0 \times 10^{5}$ & 4.00 & $4+$ \\
\hline E. coli $\mathrm{K}-12$ & ND & 0 & 0 & - \\
\hline
\end{tabular}




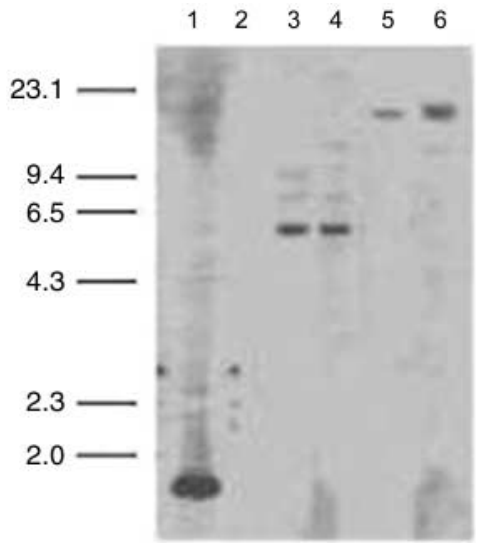

Fig. 1. Southern blot hybridisation of $P$. alcalifaciens 2939/90 and its TnphoA mutants. Chromosomal DNA from all isolates was digested with BamHI and probed with digoxigeninlabelled kanamycin resistance gene. Lane 1, amplified kanamycin resistance gene (positive control); 2, P. alcalifaciens 2939/90; 3, mutant 23; 4, mutant 47; 5, mutant 63; 6, mutant 78.

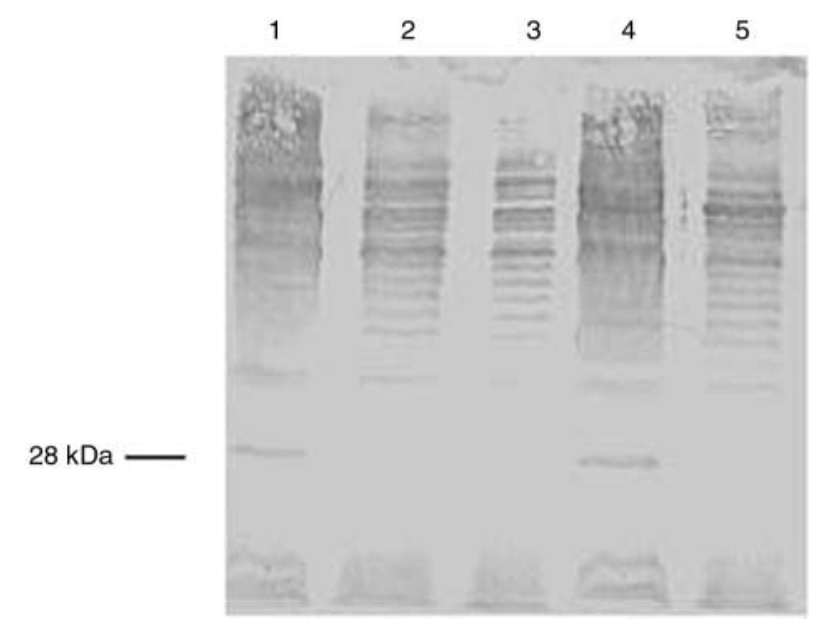

Fig. 2. Immunoblot analysis of secreted proteins of $P$. alcalifaciens 2939/90 and its TnphoA mutants. The proteins were separated by SDS-PAGE, transferred to nitrocellulose membrane and probed with rabbit polyclonal antibody to P. alcalifaciens 2939/90 and enzyme-conjugated anti-rabbit immunoglobulin. Lane 1, P. alcalifaciens 2939/90; 2-5, TnphoA mutants 23, 47, 51 and 63, respectively.

secreted proteins in many bacteria [14-16]. In the present study, four mutants of PA that had negligible invasiveness and actin condensation in HEp-2 cells compared with the parent strain were generated by the same strategy. The reduction observed in these properties could not be attributed to differences in motility and cell association between the parent strain and the mutants, as these properties were not altered in the mutants compared to the parent strain. Single TnphoA insertions were located in fragments of two different sizes in these mutants; this suggested that more than one locus is involved in invasion. All four mutants failed to secrete a $28-\mathrm{kDa}$ protein. In many bacteria, including Salmonella spp. [17] and Shigella spp. [18], secreted proteins are involved in invasion of mammalian cells. It is likely that the $28-\mathrm{kDa}$ secreted protein may also be involved in the invasiveness of
$P$. alcalifaciens. When the lysed whole-cell pellet was analysed in immunoblot, no difference in protein profile was observed between the parent strain and the mutants. This suggested that other proteins may not be involved in the invasion process. It should be now possible to perform molecular characterisation of gene(s) involved in invasiveness of $P$. alcalifaciens with the help of these mutants. Some further studies involve sequencing the $\operatorname{Tn} p h o A$ insertion site, comparison of sequence with sequence data in the literature, cloning the gene, complementation of mutants with the cloned gene and expression of the cloned gene. The present study has added $P$. alcalifaciens to the list of pathogenic bacteria whose virulence determinants can be studied by TnphoA mutagenesis.

This research was supported by the ICDDR,B: Centre for Health and Population Research, which is supported by countries and agencies that share its concern for the health problems of developing countries. Current donors providing unrestricted support include: the aid agencies of the governments of Australia, Bangladesh, Belgium, Canada, the Netherlands, Sweden, Sri Lanka, Switzerland, the UK and the USA; international organisations include the United Nations Children's Fund (UNICEF).

\section{References}

1. Aleksic S, Bockemuhl J. Yersinia and other Enterobacteriaceae. In: Murray PR, Baron EJ, Pfaller MA, Tenover FC, Yolken RH (eds) Manual of clinical microbiology, 7th edn. Washington, DC, ASM Press. 1999: 483-496.

2. Haynes J, Hawkey PM. Providencia alcalifaciens and travellers' diarrhoea. BMJ 1989; 299: 94-95.

3. Albert MJ, Faruque ASG, Mahalanabis D. Association of Providencia alcalifaciens with diarrhea in children. J Clin Microbiol 1998; 36: 1433-1433.

4. Albert MJ, Alam K, Ansaruzzaman M et al. Pathogenesis of Providencia alcalifaciens-induced diarrhea. Infect Immun 1992; 60: $5017-5024$.

5. Mathan M, Mathan VI, Albert MJ. Electron microscopic study of the attachment and penetration of rabbit intestinal epithelium by Providencia alcalifaciens. J Pathol 1993; 171: 67-71.

6. Albert MJ, Ansaruzzaman M, Bhuiyan NA, Neogi PKB, Faruque ASG. Characteristics of invasion of HEp-2 cells by Providencia alcalifaciens. J Med Microbiol 1995; 42: $186-190$.

7. Janda JM, Abbott SL, Woodward D, Khashe S. Invasion of HEp-2 and other eukaryotic cell lines by Providenciae: further evidence supporting the role of Providencia alcalifaciens in bacterial gastroenteritis. Curr Microbiol 1998; 37: 159-165.

8. Sobreira M, Leal NC, Magalhães M, Guth BEC, Almeida AMP. Molecular analysis of clinical isolates of Providencia alcalifaciens. J Med Microbiol 2001; 50: 29-34.

9. Manoil C, Beckwith J. TnphoA: a transposon probe for protein export signals. Proc Natl Acad Sci USA 1985; 82: 8129-8133.

10. Taylor RK, Manoil C, Mekalanos JJ. Broad-host-range vectors for delivery of TnphoA: use in genetic analysis of secreted virulence determinants of Vibrio cholerae. J Bacteriol 1989; 171: $1870-1878$.

11. Mounier J, Bahrani FK, Sansonetti PJ. Secretion of Shigella flexneri Ipa invasins on contact with epithelial cells and subsequent entry of the bacterium into cells are growth stage dependent. Infect Immun 1997; 65: 774-782.

12. Sambrook J, Fritsch EF, Maniatis T. Molecular cloning: a laboratory manual, 2nd edn, vol 3. Cold Spring Harbor, NY, Cold Spring Harbor Laboratory Press. 1989: E3-E5 and 18.3-18.7.

13. Towbin H, Staehelin T, Gordon J. Electrophoretic transfer of proteins from polyacrylamide gels to nitrocellulose sheets: procedure and some applications. Proc Natl Acad Sci USA 1979 ; 76: 4350-4354. 
14. Taylor RK, Miller VL, Furlong DB, Mekalanos JJ. The use of phoA gene fusions to identify a pilus colonization factor coordinately regulated with cholera toxin. Proc Natl Acad Sci USA 1987; 84: 2833-2837.

15. Donnenberg MS, Calderwood SB, Donohue-Rolfe A, Keusch GT, Kaper JB. Construction and analysis of TnphoA mutants of enteropathogenic Escherichia coli unable to invade Hep-2 cells. Infect Immun 1990; 58: 1565-1571.

16. Allaoui A, Sansonetti PJ, Parsot C. MxiJ, a lipoprotein involved in secretion of Shigella invasins, is homologous to YscJ, a secretion factor of the Yersinia Yop proteins. J Bacteriol 1992; 174: 7661-7669.

17. Kubori T, Matsushima D, Nakamura J et al. Supramolecular structure of Salmonella typhimurium type III protein secretion system. Science 1998; 280: 602-605.

18. Blocker A, Gounon P, Larquet E et al. The tripartite type III secretion of Shigella flexneri inserts IpaB and IpaC into host membrane. J Cell Biol 1999; 147: 683-693. 